\title{
Product, Price, Distribution and Promotion as Determinants of Freight Forwarder Choice
}

\author{
Wulyo \\ Sekolah Tinggi Ilmu Administrasi \& Manajemen Kepelabuhanan \\ Barunawati Surabaya, Indonesia
}

\begin{abstract}
The aim of this study is to examine the influence of Product, Price, Distribution and Promotion as Determinants of Costumers' Freight Forwarder Choice either individually or jointly. Variables of Product, Price, Distribution and Promotion serve as independent variables while the dependent variable is Freight Forwarder Choice. The study was conducted on randomly selected 100 consumers of Sea Fright in the city of Surabaya, East Java. Using mix method, sequential explanatory design is applied where quantitative come first. The study both quantitatively and qualitatively reveals that there is a positive significant relationship among variables under the following distribution of coefficient of correlation: Product to Freight Forwarder Choice = 0.052, Price to Freight Forwarder Choice $=0.172$, Distribution to Freight Forwarder Choice $=0.264$, Promotion to Freight Forwarder Choice $=0.323$ and when tested together it produces coefficient of correlation $=0.712$, indicating the existence of other $28.8 \%$ variables not including in the model affecting factors affecting choice among the sea freight consumers.
\end{abstract}

Keywords: Product, Price, Distribution, Promotion, Costumers' Intention, Sea Freight.

\section{INTRODUCTION}

Like that in most developing countries, the service sector is becoming increasingly important to the Indonesian economy. Indonesia's logistics services sector plays a significant role in its rising economic importance. Further, since logistics is a derived demand, its competitiveness is linked with that of the industries that it serves.

Freight forwarder is a specialist trade provides a wide range of functions and facilities for the transport of goods (Murphy and Daley, 2000). It has long been known that freight forwarder is a key intermediary involved in the transport of goods (cargo) from the point of origin to the point of destination by sea or air. Lai and Cheng (2004) explains that the main business of the freight forwarder is purchase transportation services from a variety of shipping or ship owners and make a series of delivery of some shippers in small amounts or large, to a specific destination with a cheaper price. From this perspective freight services forwarding is deemed as a company trying to achieve two goals at once that is customer satisfaction (product delivery on the conditions, time and place) as well as cost savings (avoid activities and unnecessary costs to handle their own affairs cargo and documents). Murphy and Daley (2000) speculated that the freight forwarding industry is undergoing tremendous development related to regulatory changes, technological advances and pressure from customers and competitors who require freight forwarding company continues to grow to survive and be successful. This also requires the forwarding company to work hard and work smart in determining strategy right for growth.

PT. Tanto Intim Line is one of notable forwarding freight in Surabaya, the second biggest city of Indonesia where big harbours are located. The reality is that to become the the market leader as the company expected is not always easy, especially the era of global trade and the development of information and technology as well as many competitors. Implementation of strategies into the management policies to be more excelled in competing to increase revenue and sales volume are necessarily conducted by the strategic orientation and strategic marketing mix product, price, promotion, sales / distribution, market entry and management of customer / consumer care). On the other hand product policies and policy of pricing need support from suppliers considering the position of the business is as an intermediary forwarder or Third Party Logistics (3PL). Over the years the 
focus of business marketing has been on identifying and segmenting markets that have consumers with a capacity to consume, who can pay a sustainable price for the product, who have access to the product and support structures which enhance purchase and who also respond to traditional integrated marketing communications. This is the business model that has shaped the business of multi-nationals (MNCs) and small to medium size enterprises (SMEs) in the developed world and in many developing countries.

Based on the background and the results of the identification of the problem, the formulation of the problem is:

1. Does product positively affect freight forwarder choice?

2. Does price positively affect freight forwarder choice?

3. Does distribution positively affect freight forwarder choice?

4. Does promotion positively affect freight forwarder choice?

5. Do product, price, distribution, and promotion simultaneously affect freight forwarder choice?

\section{Literature REVIEW}

Professor "Jerome McCarthy" marketing mix early 1960s proposed consisting of four main factors (product, price, place or distribution and promotion) that each of factors contains multiple activities. Bay, Petrizzi and Gill (2008) confirmed that when an organization applied marketing mix in their business, it will help them to increase the sales and profits of their organization, hence, achieving their marketing level. A product is anything for attention, acquisition, use or consumption can be marketed and can to satisfy a need or want. Product is something more tangible goods. Product includes physical objects, services of persons, places, organizations, manufacturer idea or a combination of these (Kotler \& Armstrong, 2000). About major components of the product can be cited, such as: product variety, quality, design, features and facilities of product, brand, packaging, size of product, service, guarantees, return the product (Maleki, et.al, 2013). Price refers to the amount of money that a person must pay to use a product. A person may purchase property one or more product or has the right of limited use. Set a price for a product requires a deep understanding of the symbolic role that price plays a role in determining the product in target market. The price of a product in the customer's mind is not the costs expended for to produce. Goods costs to the consumer are the one thing that every consumer should losing for access to the benefits and points of ownership or use of a product. Reducing nonfinancial cost of ownership or use of goods is one of the things companies are doing to enhance the value of their goods to the customers. In case of success this strategy reduces the total cost of product for a consumer and still marketers revenue remains constant or increases (Hawkins, 2005). Distribution is delivery the desired product and service to the customer on time and desired place. There is an overall strategy about distribution. In the first strategy organization direct and in second strategy by helping distributors provide their goods and services to consumers.

Members of distribution channels are responsible for the following main duties:

Market informing: gathering and distributing news and market research about actors and forces in marketing environment that is needed planning and assistance on the exchange.

- Promotion and advertise: preparing and distributing information encouraged about the goods.

- Contact: search and communicate with potential buyers.

- Compliance products: shaping and matching goods with the buyer's needs.

- Negotiate: reaching agreement on price and other conditions of the transaction so that the transaction can be provided (Maleki et,al, 2013). Promotion is all the communication tools that can deliver the message to the intended audience. Basically promotion is set of activities to inform, persuade and influence that completely linked (Gilaninia et.al, 2013).

Elements in marketing mixare the controllable tools that will reflect to customer's satisfaction (Shankar et.al, 2011). A clear understanding of elements in marketing mix will help business providers to influence potential and current customers to continue doing business and become loyal customers. In this context, forwarding industry can use marketing mix elements in order to capture the factors that will lead customers to select freight forwarder from that particular organizations instead of other competitors. 
The wide acceptance of the Mix among field marketers is the result of their profound exposure to this concept during college years, since most introductory marketing manuals embrace it as "the heart of their structure" and identify the 4Ps as the controllable parameters likely to influence the consumer buying process and decisions (Brassington and Pettitt 2003). An additional strong asset of the mix is the fact that it is a concept easy to memorise and apply. In the words of David Jobber (2001): "The strength of the 4Ps approach is that it represents a memorable and practical framework for marketing decision-making and has proved useful for case study analysis in business schools for many years".

The main reasons the marketing mix is a powerful concept are It makes marketing seem easy to handle, allows the separation of marketing from other activities of the firm and the delegation of marketing tasks to specialists; and - The components of the marketing mix can change a firm's competitive position (Grönroos, 1994). The marketing mix concept also has two important benefits. First, it is an important tool used to enable one to see that the marketing manager's job is, in a large part, a matter of trading off the benefits of one's competitive strengths in the marketing mix against the benefits of others. The second benefit of the marketing mix is that it helps to reveal another dimension of the marketing manager's job. All managers have to allocate available resources among various demands, and the marketing manager will in turn allocate these available resources among the various competitive devices of the marketing mix.

However, Möller (2006) highlighted that the shortcomings of the 4Ps marketing mix framework, as the pillars of the traditional marketing management have frequently become the target of intense criticism.

Understanding the importance of consumer in definition of marketing found as human activity including freight forwarder choice is directed at satisfying needs and wants through exchange processes (Ardestani et.al, 2003). From this definition emerge two key activities related to marketing. First, the seller will try to meet the needs and demands of the target market and the second, the marketing involved study exchange process which be transferred the party's resources to another.

Based on above description, hypothesis formulated is: product significantly affects freight forwarder choice (H1), price significantly affects freight forwarder choice $(\mathrm{H} 2)$, distribution significantly affects freight forwarder choice $(\mathrm{H} 3)$, promotion significantly affects freight forwarder choice (H4), product, price, distribution and promotion simultaneously affect freight forwarder choice (H5).

\section{Data Collection}

This study applies mix method with direct observation to the field aimed at analyzing the phenomenon occur when the research took place then confirm the finding by using direct depth interview. This way, writers apply Sequential Explanatory Mixed Methods. Descriptive statistics and quantitative analysis are used for finding initial solution to the problem encountered. The sample of this study were 100 customers using the service of the respective company located in Surabaya, EastJava Indonesia.

Techniques of data collection in this study is in the form of questionnaire. The normality assumption is prerequisites to proceed to further test. Analysis is conducted with multiple linear regression and hypothesis testing is performed at a significance level of 0.05 .

Depth interview with managers of the company were performed to confirm the result of quantitative findings. The implication of the research findings is then discussed.

\section{RESUlT AND DiSCUSSION}

The teachers of listed organisations were asked to participate in the survey by responding their opinions for five different measures in product, price, distribution and freight forwarder choice. The normality is performed with Lilliefors test. Data are normally distributed as the value of each variable is not exceeding the critical value for Lilliefors test. The Lilliefors normality test values for product, price, distribution to freight forwarder choice are $0.052,0.061$ and 0.063 respectively below the critical value of 0.093 for $\mathrm{n}=100$.

\subsection{The Effect of Product to Freight Forwarder Choice}

Hypothesis testing confirms that product positively affects freight forwarder choice with correlation coefficient value of 0.228 and the coefficient of determination $=0.052$. This means that only $5.2 \%$ of 
freight forwarder choice is determined by product, while the other $94.8 \%$ is contributed by other variables. Similarly, result of qualitative research interviews, observation and documentation confirms the tendency of the relationship between products with freight forwarder choice. This finding strengthens the quantitative research hypothesis results testing that there is a positive significant relationship between product and freight forwarder choice.

The finding supported the finding of Shinghal, \& Fowkes, T., (2002) that found out frequency of service is an important attribute determining mode choice.

In consumer behavior, this finding is in line with Ghanimata \& Kamal (2012) conducting the research on consumers who ever or frequently come on the Bandeng Juwana Elrina Semarang then found out that price variables have the lowest influence compared to variables of location and product.

Thus, the analysis of this study further supports the results of previous studies regarding the existence of a positive relationship between product and selection of particular service in Asia with particular reference to developing country of Indonesia.

\subsection{The Effect of Price to Freight Forwarder Choice}

Hypothesis testing confirms that price positively affects freight forwarder choice with the coefficient of determination $=0.1722$. This means that $17.2 \%$ of freight forwarder choice is determined by price variable, while the other $82.78 \%$ is contributed by other variables. Similarly, result of qualitative research interviews confirms the tendency of the relationship between Price with freight forwarder choice. This finding strengthens the quantitative research hypothesis results testing that there is a positive significant relationship between price and freight forwarder choice.

This is consistent with Nusair et.al, (2010) who investigate the effects of price discount frames and price discount levels on consumer perceptions about the quality of the service product, the value of the discount, their purchase intentions and their willingness to spread the word of mouth about the discount savings across different types of services. The findings indicate that price discount frames and discount levels do affect consumers' perceptions on the value of the discount, the quality of the service, their intention to purchase.

Previous study in Indonesia also has shown that price and service selection has a positive relationship, e.g., Fure (2013). This research showed that location, product diversity, price, and service quality had significant impact on the buying interest at traditional market.

Thus, the analysis of this study further supports the results of previous studies regarding the existence of a positive relationship between price and service choice in Asia with particular reference to developing country of Indonesia. The better the result of price on those dimensions, the higher intention to select the service will be displayed.

\subsection{The Effect of Distribution to Freight Forwarder Choice}

Hypothesis testing confirms that distribution positively affects freight forwarder choice with the coefficient of correlation $=0.514$ and coefficient of determination $=0.264$. This means that $26.4 \%$ of freight forwarder choice is determined by distribution variable, while the other $73.6 \%$ is contributed by other variables. Similarly, result of qualitative research interviews confirms the tendency of the relationship between distributions with freight forwarder choice. This finding strengthens the quantitative research hypothesis results testing that there is a positive significant relationship between distribution and freight forwarder choice.

This finding is in line with Sikdar, \& Vel, P. (2010) that found distribution is crucial in the eventual acceptance and sales of a new product in the market as it determines the availability of the new product to customers. In this regard, it is worth mentioning that the fit between product and the delivery system is the single most important variable, affecting the success of new services and products. As distribution strategy plays a role in enabling the availability and application of the product in the marketplace, therefore the distribution strategy employed by the forwarding company would impact the nature of "market support" capability that can be provided.

Thus, the analysis of this study further supports the results of previous studies regarding the existence of a positive relationship between distribution and service choice in Indonesia which is also applicable in freight forwarding industry. 


\subsection{The Effect of Promotion to Freight Forwarder Choice}

Hypothesis testing confirms that promotion positively affects freight forwarder choice with the coefficient of correlation $=0.323$ and coefficient of determination $=0.104$. This means that $10.4 \%$ of freight forwarder choice is determined by distribution variable, while the other $89.6 \%$ is contributed by other variables. Similarly, result of qualitative research interviews confirms the tendency of the relationship between promotion with freight forwarder choice. This finding strengthens the quantitative research hypothesis results testing that there is a positive significant relationship between promotion and freight forwarder choice.

This finding is in line with Khasanah (2014) who examine and analyze how the influence of brand image, quality of service, and the promotion of the use of decision DHL Global Forwarding services as well as to identify and analyze the most dominant factor affecting freight forwarder choice. The research concluded that variables of brand image, quality of service and promotion explains the purchase decision of $50.4 \%$ and the remaining $49.6 \%$ is influenced by other variables. Thus, the analysis of this study further supports the results of previous studies regarding the existence of a positive relationship between promotion and freight forwarder choice in Indonesia.

\subsection{Interaction of Product, Price, Distribution and Promotion to Freight Forwarder Choice}

When tested together, hypothesis testing results show that there is a significant relationship between product, price, distribution and promotion to freight forwarder choice. The correlation of coefficient values $=0.884$ and the coefficient of determination $=0.712$. This means that $71.2 \%$ of freight forwarder choice is caused by variables of product, price, distribution and promotion while $28.8 \%$ is contributed by other variables not included in the model. Result of qualitative research interviews confirm the relationship among product, price, distribution and promotion to freight forwarder choice. This finding strengthens the quantitative research hypothesis results testing that there is a positive significant relationship among those mentioned variables. Qualitative research also reveals that other factors affecting freight forwarder choice in the respective company are efficiency, shipping frequency, adequate infrastructure, location, port charges, quick response to port users' needs and reputation for cargo damage.

\section{Conclusion}

The findings reveal that there is a positive and significant direct effect between the product, price, distribution and promotion to freight forwarder choice.

Based on the initial design of the constellation between variables, the results showed that the contribution of product to freight forwarder choice is $0.052 \%$, price is $0.172 \%$, distribution is $0.264 \%$ and promotion is $10.4 \%$ indicating the highest individual contribution to the freight forwarder choice is distribution. When combined together, contribution of the four variables of product, price, distribution and promotion reaches $71.2 \%$ indicating the contribution of other variables not included in the model to predict freight forwarder choice are $28.8 \%$ confirming this model is of good-fit. Other researchers wishing to conduct similar studies may include other variables such as high port efficiency, good geographical location, low port charges, adequate infrastructure, wide range of port services, connectivity to other ports, adequate infrastructure and others.

Although the survey has been limited to a sample of freight forwarders in Surabaya, Indonesia, the results provide a useful empirical contribution to this increasingly important issue of port choice in this increasingly competitive trading environment in the context of a scant literature on port choice and offer an additional basis for further study into port choice and performance from the freight forwarders' perspective within the overall supply chain.

\section{REFERENCES}

Ardestani, A. S., Mirabi, V. R., Kazemi, M. A. A., \& Esmailifar, B. A Study on the Effect of Marketing Advertisements and Price Promotion to Brand equity in Iranian Insurance Industry.

Armstrong, G., \& Kotler, P. Marketing an introduction 2000.

Bay, S., Gill, P., Petrizzi, R., \& Rath, P. M. (2008). The why of the buy.

Brassington, F., \& Pettitt, S. (2003). Principles of Marketing Pitman. London: pg, 312-24.

David, J. (2001). Principles and Practice of marketing. Mc-Graw Publishing Company. 
Fure, H. (2013). Lokasi, Keberagaman Produk, Harga, dan Kualitas Pelayanan Pengaruhnya Terhadap Minat Beli Pada Pasar Tradisional Bersehati Calaca. JURNAL RISET EKONOMI,MANAJEMEN, BISNIS DAN AKUNTANSI, 1(3).

Gilaninia, S., Taleghani, M., \& Azizi, N. (2013). Marketing Mix And Consumer Behavior. Kuwait Chapter of the Arabian Journal of Business and Management Review, 2(12), 53.

Grönroos, C. (1994). From marketing mix to relationship marketing: towards a paradigm shift in marketing. Management decision, 32(2), 4-20.

Ghanimata, F., \& Kamal, M. (2012). Analisis Pengaruh Harga, Kualitas Produk, dan Lokasi Terhadap Keputusan Pembelian (Studi pada Pembeli Produk Bandeng Juwana Elrina Semarang) (Doctoral dissertation, Fakultas Ekonomika dan Bisnis).

Hawkins, G. (2005). Process for creating and disseminating marketing initiatives to specific consumers or specific consumer groups. U.S. Patent Application No. 11/283,202.

KHASANAH, I. (2014). ANALISIS PENGARUH CITRA MEREK, KUALITAS LAYANAN, DAN PROMOSI TERHADAP KEPUTUSAN PENGGUNAAN JASA (Studi pada Pengguna Jasa DHL Global Forwarding Semarang Branch) (Doctoral dissertation, Fakultas Ekonomika dan Bisnis).

Lai, K. H., \& Cheng, T. C. E. (2004). A study of the freight forwarding industry in Hong Kong. International journal of logistics Research and Applications, 7(2), 71-84.

Maleki, A., Ansari, A., \& Safari, A. (2013). A Study of Market Orientation and Its Effect on Small to Medium Sized Enterprises of Informatics Industry Located in Tehran. Journal of Novel Applied Sciences Available online at www. jnasci. Org, 1150-1159.

Möller, K. (2006). The Marketing Mix Revisited: Towards the 21st Century Marketing by E. Constantinides.

Murphy, P. R., \& Daley, J. M. (2000). An empirical study of Internet issues among international freight forwarders. Transportation journal, 39(4), 5-13.

Nusair, K., Jin Yoon, H., Naipaul, S., \& Parsa, H. G. (2010). Effect of price discount frames and levels on consumers' perceptions in low-end service industries. International Journal of Contemporary Hospitality Management, 22(6), 814-835.

Shankar, V., Inman, J. J., Mantrala, M., Kelley, E., \& Rizley, R. (2011). Innovations in shopper marketing: current insights and future research issues. Journal of Retailing, 87, S29-S42.

Shinghal, N., \& Fowkes, T. (2002). Freight mode choice and adaptive stated preferences. Transportation Research Part E: Logistics and Transportation Review, 38(5), 367-378. 